\title{
PREVALENCE OF ENTEROPARASITOSIS IN THE INDIGENOUS COMMUNIT Y OF MATO GROSSO, BRAZIL: A LOOK INTO THE SANITATION AND ETHNO-DEVELOPMENT
}

\section{Leonir Evandro Zenazokenae}

Enfermeiro. Egresso da Universidade do Estado de Mato Grosso - UNEMAT, Tangará da Serra/MT, Brasil.

Ana Cláudia Pereira Terças-Trettel

Doutora em Medicina Tropical IOC/Fiocruz, Brasil.

\section{Vagner Ferreira do Nascimento}

Doutor em Bioética pelo Centro Universitário São Camilo, Brasil.

\section{Thalise Yuri Hattori}

Mestre em Ciências da Saúde pela Universidade Federal da Grande Dourados - UFGD, Brasil.

\section{Mariana Atanaka}

Doutora em Saúde Pública pela Escola Nacional de Saúde Pública, Brasil.

\section{Elba Regina Sampaio de Lemos}

Doutora em Medicina Tropical pelo Instituto Oswaldo Cruz. Pesquisadora do Instituto Oswaldo Cruz, Rio de Janeiro/RJ, Brasil.

\section{Márcio Neves Bóia}

Doutor em Medicina Tropical pelo Instituto Oswaldo Cruz. Pesquisador do Instituto Oswaldo Cruz, Rio de Janeiro/RJ, Brasil.

\begin{abstract}
The intestinal parasitic diseases directly affect the quality of life of indigenous populations, because of vulnerabilities they experience. This study aimed to understand the prevalence of intestinal parasites among the Haliti-Paresí and relate with sanitation and ethno-development. It is a quantitative and cross-sectional study on indigenous Utiaritiland where reside the Haliti-Paresí, in the middle region northern Mato Grosso, Brazil. Data collection occurred in 2015, from interview with application of semi-structured form and collection of feces for coprological survey.Forty-three indigenous people participated in the study, of an average age of 30.9 years old, mostly women, and a predominance of basic education. The prevalence of enteroparasitosis was $46.6 \%$, predominantly among men, reaching all adolescents, followed by children, without the influence of schooling in the rate of infection. Nine species were detected, being six pathogenic, Giardia duodenalis, Entamoebahistolytica, Ancilostomídeo, Blastocystishominis, Hymenolepis nana and Rodentolepis nana, in addition to three non-pathogenic, Iodamoebabutscblii, Entamoeba coli and Endolimax nana. The sanitation conditions, associated with cultural habits, point to the need for improvement in sanitation, since we detected a high prevalence of intestinal parasitoses in this study. The ethno-development may be crucial as strategies for the maintenance of culture in balance with health and sanitary development.
\end{abstract}

KEY WORDS: Epidemiology; Parasitic Diseases, Health of Indigenous Peoples; Social Planning.

\section{PREVALÊNCIA DE ENTEROPARASITOSES EM COMUNIDADE INDÍGENA DE MATO GROSSO, BRASIL: UM OLHAR SOBRE O SANEAMENTO E ETNODESENVOLVIMENTO}

RESUMO: As doenças parasitárias intestinais impactam diretamente na qualidade de vida das populações indígenas, em decorrência das vulnerabilidades que vivenciam. Objetivou-se conhecer a prevalência das parasitoses intestinais entre os Haliti-Paresí e relacionar com o saneamento e etnodesenvolvimento. Trata-se de um estudo quantitativo e transversal na terra indígena Utiariti onde residem os Haliti-Paresí, na região médio Norte de Mato Grosso, Brasil. A coleta de dados ocorreu em 2015, a partir de entrevista com aplicação de formulário semiestruturado e coleta de fezes para inquérito coprológico. Participaram do estudo 43 indígenas, com idade média de 30,9 anos, maioria mulheres e predomínio do ensino fundamental. A prevalência de enteroparasitoses foi de 46,6\%, predominando entre os homens, atingindo todos os adolescentes, seguido pelas crianças, sem influência da escolaridade na taxa de infecção. Nove espécies foram detectadas, sendo seis patogênicos, Giardiaduodenalis, Entamoebabistolytica, Ancilostomídeo, Blastocystishominis, Hymenolepis nana e Rodentolepis nana, além
Autor correspondente

Ana Claudia Pereira Terças-Trettel

enfanacnp@gmail.com 
de três não patogênicas, Iodamoebabutschlii, Entamoeba coli e Endolimax nana. As condições de saneamento associadas aos hábitos culturais apontam para necessidade de melhoria no saneamento, uma vez que detectamos alta prevalência de parasitoses intestinais neste estudo. $\mathrm{O}$ etnodesenvolvimento poderá ser fundamental como estratégias de manutenção da cultura em equilíbrio com a saúde e desenvolvimento sanitário.

PALAVRAS-CHAVE: Doenças parasitarias; Saúde de populações indígenas; Planejamento social.

\section{INTRODUCTION}

Although in recent decades the morbidity and mortality profile of indigenous peoples come undergoing several modifications, with the expansion of chronic diseases and external causes, infectious and parasitic diseases still remain as the main causes of mortality ${ }^{1,2}$.

The low effectiveness of programs to control intestinal parasitism and diarrhea, associated with precarious conditions of sanitation, territorial restriction and increasing environmental degradation, especially around the indigenous lands. With the increase of morbidity for free riding among the indigenous people, what makes us reflect on the importance of conducting studies on this portion of the Brazilian population ${ }^{3}$.

In Brazil, according to the census conducted in 2010, there are 817,963 indigenous people; and in Mato Grosso live 42,538 Indians, who are assisted by the Special Indigenous Health Districts (DSEI's) Cuiabá, Xavante, Vilhena, Xingu, Kayapo ofMato Grosso and Araguaia ${ }^{4}$.

The ethnicity Haliti-Paresí stands out in Mato Grosso by its socio-political interaction, by the constant advances in its ethno-development and good relationship with the "non-Indians",

The ethno-development has in response to the hegemonic model of economic development of that time. The ethno-development is the autonomy of the Indians, the exploration of their traditional knowledge and respect the ways chosen by them to build their future projects. 7,8Applied to health, ethno-development proposes assistance based on disease prevention and health promotion, as well as the modernization and integration between the indigenous traditional medicine and western medicine, with an emphasis on the actions of sanitation as primary determinants of health ${ }^{8,9}$.

The villages of Haliti-Paresí, located in the region of Middle America Mato-Grossense, are distributed in nine indigenous lands. Although most have access to electricity and water from wells, only half of the Community has access to basic sanitation, a situation that needs to be overcome so that subsequently there is reduction of infectious and parasitic disease ${ }^{10}$. In this sense, the study has the objective to know the prevalence of parasitic diseases between Haliti-Paresí and its relationship with the sanitation and ethno-development.

\section{METHODOLOGY}

It is a quantitative, cross-sectional study, conducted in the indigenous land Utiariti, where reside the Haliti-Paresí, in the middle region north of Mato Grosso (MT) state, Brazil.

The study was carried out in five villages Haliti-Paresí belonging to Utiaritiindigenous land in the municipality of Campo Novo do Parecis-MT. The data were collected in the period from December 2014 to July 2015, by the researchers, in the whole universe populated villages Utiariti, Seringal, QuatroCachoeiras, Bacaval, and Wazare (Figure 1).

Live in these villages, 169 indigenous people, these were found to be 118, who participated in data collection and received the universal collector for collection of feces. However, only 43 (36.4\%) gave the sample for analysis, composing the final sample. The planning and implementation of data collection, it was through initial contact with the chiefs of each village to the schedule of data collection with 30 days in advance. The team was composed of three nursing students and two nurses. Daily, the team returned to the nearest city, Campo Novo do Parecis-MT, in order to stow the samples and for typing duo from the database.

During the data collection period, a mobile laboratory was set up in each village, in the place indicated by the cacique. Held visits for those who have not moved up to the point of support in the village.

Initially, the team presented the project's aims for the indigenous community. After the talks mediated 


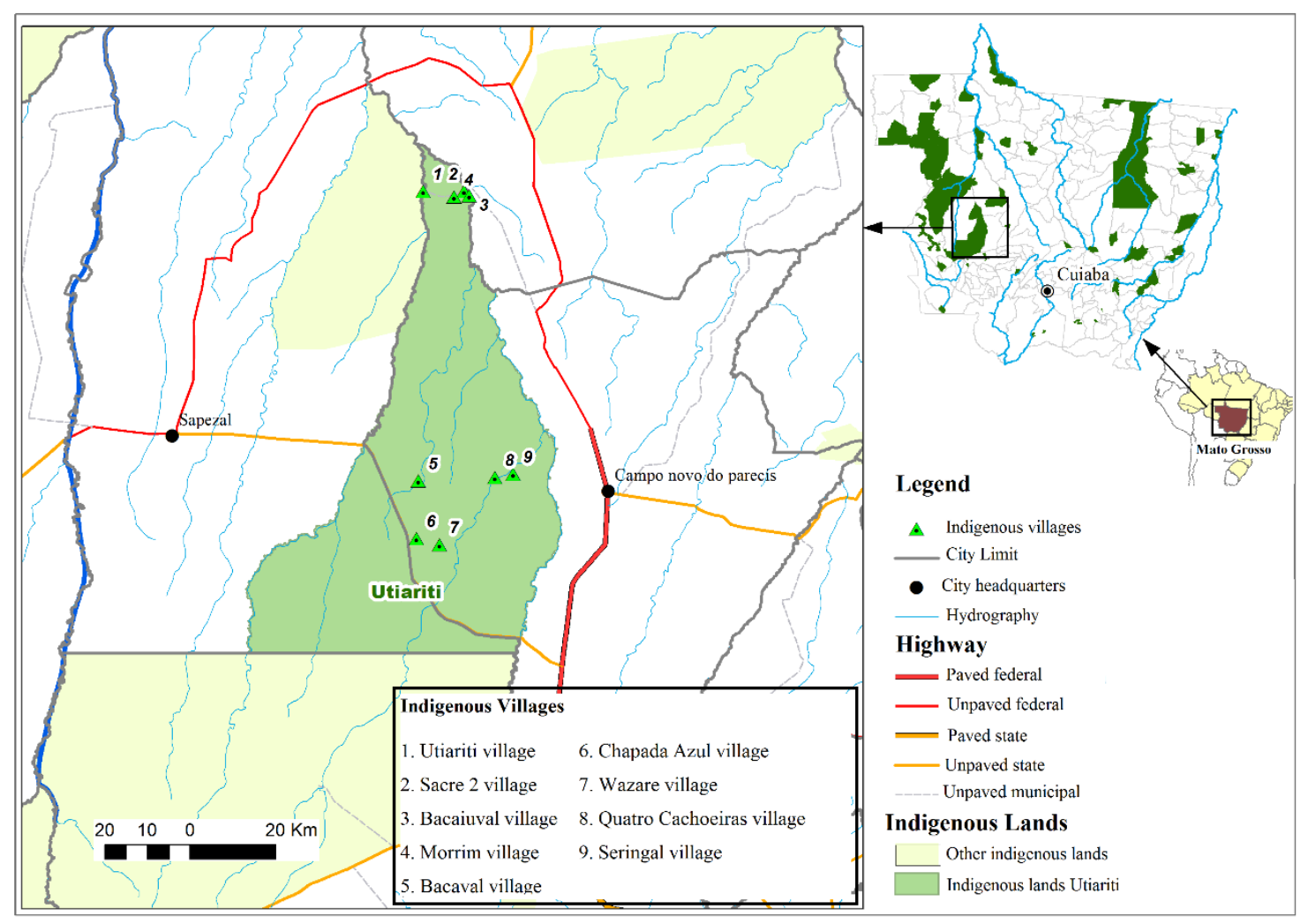

Figure 1. Locality of the villages Utiariti, Bacaval, Quatro Cachoeiras, Seringal and Wazare, indigenous land Utiariti, Mato Grosso, 2017. Source: Adapted from Terças, 2016.

by the cacique was the delivery of the Free and Informed Consent Form (ICF) for more than 18 years old and the terms for children and adolescents ( 7 to 17 years of age). After reading the term accompanied by one of the researchers, occurred the confirmation of voluntary participation and the signature of the same ${ }^{11}$.

Data were collected by means of interviews with semi-structured guide drawn up by the researchers, containing questions that addressed the sociocultural variables and related to sanitation. The interviews were conducted individually, with a duration of 20 minutes, were subsequently delivered the pots collectors of feces duly identified and carried to the guidance of collecting and packing until the return of the team.

The next day in the afternoon, the team traveled the households to collect feces collectors, with preserved in a solution of MIF (mertiolatediiodo-formaldehyde) those were taken to the laboratory base, and subsequently, forwarded to the Laboratory of Biology and Parasitology of wild mammals reservoirs of the Oswaldo Cruz Institute. They were processed by the technique of centrifugal-sedimentation with ethyl acetate
(Ritchie modified by Young) $)^{12,13}$.

The technique is based on the spontaneous sedimentation of evolutionary forms of parasites and some of the material obtained after filtration is deposited in a cup of conical bottom with a capacity of $250 \mathrm{ml}$ with subsequent addition of distilled water to complete the volume. After 24 hours of rest for the sedimentation of the material, a drop of sediment is transferred to a blade that after being covered by a coverslip is read in a microscope with an increase of $40 \mathrm{X}$.

The data from the data collection were systematized in an electronic spreadsheet, and included in the data banks with dual typing in Excel. After verification and consolidation, the data were imported into the Statistical Package for the Social Sciences, version 20.0, submitted to statistical analyzes and presented in tables and graphs with absolute and relative frequency of the variables of the study.

The research followed ethical standards for research involving human beings, with certificate of appreciation $\mathrm{N}^{\circ} 04647412.0 .1001 .5541$ and opinion of approval from the Research Ethics Committee of the University 
Hospital Júlio Muller at the Federal University of Mato Grosso/UFMT under protocol $\mathrm{N}^{\circ} 018015 / 2012$ and by the National Committee for Ethics in Research (CONEP) under protocol 819.939/2014.

\section{RESULTS}

There were examined 43 samples of feces of indigenous people with ages ranging from 4 months to 80 years old, of an average of 30.9 years old (standard deviation 21.28), being 51.2\% women. Regarding schooling, there was a predominance of basic education (53.4\%) (Table 1). However, the incidence of parasitism was predominant among men, and reached the totality of adolescents (13-18 years old), followed by children under the age of $12(72.7 \%)$, without the influence of schooling in the rate of infection, since all the graduates presented intestinal parasites in analyzes performed.

Table 1. Sociodemographic characteristics of 43 indigenous Haliti-Paresí. Indigenous land Utiariti, Campo Novo do Parecis, Brazil, 2017

(Continua)

\begin{tabular}{|c|c|c|c|c|c|}
\hline \multirow{2}{*}{\multicolumn{2}{|c|}{ Variables $\mathbf{N}$}} & \multicolumn{2}{|c|}{$\begin{array}{l}\text { Parasitological } \\
\text { examinations } \\
+(\mathrm{N}=20)\end{array}$} & \multicolumn{2}{|c|}{$\begin{array}{l}\text { Total Popu- } \\
\text { lation } \\
(\mathrm{N}=43)\end{array}$} \\
\hline & & $\%$ & $\mathbf{N}$ & $\%$ & \\
\hline \multirow[t]{2}{*}{ Gender } & Male & 11 & 52,4 & 21 & 48,8 \\
\hline & Female & 09 & 40,9 & 22 & 51,2 \\
\hline \multirow[t]{5}{*}{ Age } & Under 12 years old & 08 & 72,7 & 11 & 25,5 \\
\hline & $13-18$ & 03 & 100 & 3 & 6,9 \\
\hline & $19-30$ & 02 & 22,2 & 9 & 20,9 \\
\hline & $31-60$ & 06 & 37,5 & 16 & 37,2 \\
\hline & $\begin{array}{l}\text { Greater than } 60 \\
\text { years old }\end{array}$ & 01 & 25,0 & 4 & 9,3 \\
\hline \multirow[t]{6}{*}{ Schooling } & Any year of study & 02 & 50,0 & 4 & 9,3 \\
\hline & $\begin{array}{l}\text { Is not of school } \\
\text { age }\end{array}$ & 04 & 80,0 & 5 & 11,6 \\
\hline & Preschool & 01 & 50,0 & 2 & 4,6 \\
\hline & Elementary School & 08 & 34,8 & 23 & 53,4 \\
\hline & High School & 03 & 42,8 & 7 & 16,2 \\
\hline & Higher Education & 02 & 100 & 2 & 4,6 \\
\hline
\end{tabular}

(Conclusão)

\begin{tabular}{|c|c|c|c|c|c|}
\hline \multirow{2}{*}{\multicolumn{2}{|c|}{ Variables N }} & \multicolumn{2}{|c|}{$\begin{array}{l}\text { Parasitological } \\
\text { examinations } \\
+(\mathrm{N}=20)\end{array}$} & \multicolumn{2}{|c|}{$\begin{array}{c}\text { Total Popu- } \\
\text { lation } \\
(\mathrm{N}=43)\end{array}$} \\
\hline & & $\%$ & $\mathbf{N}$ & $\%$ & \\
\hline \multirow{3}{*}{$\begin{array}{l}\text { Ethnicity } \\
\text { of origin }\end{array}$} & Paresí & 19 & 48,7 & 39 & 90,6 \\
\hline & Not Indian & 01 & 33,3 & 3 & 6,9 \\
\hline & Other ethnicities & - & - & 1 & 2,3 \\
\hline \multirow{5}{*}{$\begin{array}{l}\text { Residence } \\
\text { village }\end{array}$} & Wazare & 11 & 47,8 & 23 & 53,4 \\
\hline & Quatro Cachoeiras & 03 & 42,8 & 7 & 16,2 \\
\hline & Bacaval & 03 & 42,8 & 7 & 16,2 \\
\hline & Seringal & 02 & 50 & 4 & 9,3 \\
\hline & Utiariti & - & - & 2 & 4,6 \\
\hline \multirow[t]{3}{*}{$\begin{array}{l}\text { Type of } \\
\text { Housing }\end{array}$} & $\begin{array}{l}\text { Traditional Indige- } \\
\text { nous }\end{array}$ & 15 & 51,7 & 29 & $67,4 \%$ \\
\hline & Wood & 05 & 41,6 & 12 & $27,9 \%$ \\
\hline & Masonry \% & - & - & 2 & 4,6 \\
\hline
\end{tabular}

We observed the presence of three non-Indians and one of another ethnic group, this fact is common among the Haliti-Paresí, since they allow the interethnic marriages.

The greatest participation (53.4\%) was one of the residents of the village Wazare (23/35), followed by the villages Bacaval (7/82) and Quatro Cachoeiras(7/20). It was also observed the predominance of indigenous traditional houses and the number of residents per household ranged from 1 to 9 , with an average of 5 people. All the traditional houses had electricity and $80 \%$ have adapted the use of floor as coating on the ground. The homes had mixed furniture containing mainly sofa, TV, lockers, networks and domestic utensils produced by the Indians themselves or bought in nearby towns.

The electrical power was present in all, due to the imposition in 2008 of the federal government's program "Light for All", exception of Wazare village, inaugurated in 2013, whose energy supply was the diesel engine.

Women described activities conducted in the village as the care with the home and family, making crafts and collects in the field. Already men reported the hunting, fishing, agriculture, levying of tolls and political interaction, while the children pointed out the study as a main activity, in addition to the jokes and aid in care with the house. It is worth noting that the professions of health 
agent, nursing technician, professor, and chief were identified in a timely manner.

The Haliti-Paresíundertakes activities outside the village (18.6\%), which reflects in its interaction with other cultures. These activities were related to political and social participation in councils, associations, and governmental body, in addition to the trade of fruits collected, students of high school and undergraduate and teacher in another village.

The sanitary conditions in villages were distinct. In one of them, where there was no supply of drinking water from artesian well, the wheel of water was placed in the nearby river. With respect to the garbage, there was not observed daily collection, or even an appropriate location for the destination of the residue produced. Thus, the waste was deposited into holes next to houses and burned to reduce the volume, with the exception of the Village Wazarethat performed daily collection and buried in the garbage deposit located 400 meters away from the houses.

With regard to the destination of waste, half of the native indigenous people kept the habit to eliminate them at 100 meters from the village into a nonspecific location. The other half used communal toilets that had outlets for septic $(75 \%)$ or outdoors $(25 \%)$. The habit of washing hands is still a challenge to be overcome to become everyday life in the community.

The nutritional habits reflected the integration with the surroundings, since $72.1 \%$ practiced mixed feeding, with consumption of indigenous and traditional foods purchased in monthly shopping at a supermarket. Rice, beans, native fruit, fish, meat, and ema were the most frequently used food. Only $7 \%$ of cases, predominantly elderly, are those who preserve the culture in all its essence, and reported ingesting exclusively traditional foods.

In relation to the actions of ethno-development, it observed that the path followed by Haliti-Paresí is in line with the increasing pursuit of financial support by means of the agricultural partnership, the organization of the association for toll collection, the insertion of members in governmental bodies and the incentive for the professional training of their descendants. The impacts of this expansionist process were more evident in the areas of economic, political and educational and few incipient in health.

With the examination of stool samples, it was possible to identify $46.6 \%$ (20/43) of parasitized individuals, and of these, half with polyparasitism. Of the nine species were identified, six were pathogenic species: Giardia $d u$ odenalis, Entamoebabistolytica, Ancilostomídeo, Blastocystishominis, Hymenolepis nana, andRodentolepis nana. The other three were non-pathogenic: Iodamoebabutschlii, Entamoeba coli, andEndolimax nana (Table 2).

Table 2. Distribution of intestinal parasites in 43 indigenous Haliti-Paresí. Indigenous land Utiariti, Campo Novo do Parecis, Brazil, 2017

\begin{tabular}{|c|c|c|c|}
\hline \multirow{2}{*}{\multicolumn{2}{|c|}{ Variables $\mathbf{N}$}} & \multicolumn{2}{|c|}{$\begin{array}{c}\text { Total } \\
\text { Population } \\
(\mathrm{N}=43)\end{array}$} \\
\hline & & $\%$ & \\
\hline \multirow{4}{*}{$\begin{array}{l}\text { Number of para- } \\
\text { sites per sample }\end{array}$} & 0 & 23 & $53,4 \%$ \\
\hline & 1 & 10 & $23,2 \%$ \\
\hline & 2 & 8 & $18,6 \%$ \\
\hline & 3 & 2 & $4,7 \%$ \\
\hline \multirow{9}{*}{ Parasites } & Entamoeba coli** & 13 & $30,2 \%$ \\
\hline & Giardia duodenalis* & 4 & $9,3 \%$ \\
\hline & Endolimax nana** & 3 & $7,0 \%$ \\
\hline & Entamoeba bistolytica* & 3 & $7,0 \%$ \\
\hline & Rodentolepis nana* & 2 & $4,7 \%$ \\
\hline & Hymenolepis nana* & 2 & $4,7 \%$ \\
\hline & Iodamoeba butschlii** & 1 & $2,3 \%$ \\
\hline & Ancilostomídeo* & 1 & $2,3 \%$ \\
\hline & Blastocystis hominis* & 1 & $2,3 \%$ \\
\hline
\end{tabular}

* Pathogenic species

** Not pathogenic species

\section{DISCUSSION}

The results obtained in this study confirm the information available in medical literature on intestinal parasites in indigenous communities in Brazil, in which the prevalence is higher than the observed in the general population ${ }^{14,15}$. The intestinal parasites have a cosmopolitan distribution, and the prevalence vary, among other factors, the dependence of economic conditions of the population, with the highest rates in developing countries, especially in areas where the conditions of sanitation and health education are disabled. 
As to the participation of Haliti-Paresí, 43 (36.4\%) gave the analysis sample rate similar to that reported by Assis et al. (2013), who also obtained low return of samples of feces for a total $37,1 \%$ in the indigenous community in Minas Gerais.

There was a predominance of indigenous participation of females, a result similar to that observed in the studies by Rios et al. and Silva, but inconsistent with the research developed by researchers in other ethnic groups $^{15-18}$. The distribution of parasitism by age was observed with a higher incidence among adolescents (13-18 years, $100 \%$ ), followed by children from 0 to 12 years, given that differs from similar studies by presenting the adolescents as the most infected ${ }^{18-20}$.

The schooling showed no relevance as a determinant factor in the reduction of infection by intestinal parasites, since in this study including the indigenous people with a higher level showed $100 \%$ intestinal parasites. The historical process of schooling of Haliti-Paresí began with the foundation of the first educational institution in 1920 by Marshal Rondon. It aimed to train indigenous to the conviviality with the "civilized society". Subsequently under the responsibility of the Jesuits in education in the decade of 1930, the municipality assumed the indigenous education only at the end of year 80. 21In this context, currently in the state of Mato Grosso, there are 176 indigenous schools, 661 teachers and 11,162 students enrolled in 2005 and following the national profile, the great majority of these students $(91.9 \%)$ is studying the basic education. 10Although education is a decisive factor for the understanding of the importance of adequate sanitation and personal and collectivehygiene, it is also one of the main means of integration of the indigenous population in society. The persistence of poor health, a result of the maintenance of sanitation conditions, has been observed with the growing indigenous migration to the outskirts of cities close to the villages ${ }^{22}$.

The high prevalence of intestinal parasitism in population groups living in areas deprived of minimum conditions of sanitation prove their correlation with environmental issues and the economic differences, an event that can be observed among indigenous peoples, such as the findings of this study with the Haliti-Paresí. Moved and seated, in their majority, in different places of its origin, the indigenous population resides in locations with impoverished soils to practice subsistence agriculture, where hunting and fishing are becoming increasingly scarce $^{23}$.

\begin{abstract}
This difficulty of mobility imposed by limiting the geographic space causes the population density and promotes a relationship of increasing dependence with the non-indigenous community. In this scenario, this population is sedentary and subjected to a situation in which the sanitation is non-existent, factors that contribute to an increase in environmental pollution from fecal wastes which, consequently, provides a quick and efficient movement of eggs, cysts and larvae of parasites ${ }^{23}$.
\end{abstract}

Thus, the enteroparasitosisin indigenous communities have high rates and become a challenge to promote the health and quality of life of those communities ${ }^{16,}$ $20,23,24$. In addition to the behavioral risks as precarious personal hygiene habits, cultural and menus, observed in populations of low socioeconomic level.In the indigenous communities, other factors contribute to the increase of these indexes as the practice of eating with hands, to defecate in the environment, do not wear shoes, drinking untreated water in association with the lack of basic sanitation $^{16,18,19,20,25}$.

Despite being a still incipient process, one needs to register a growing processing. The academic formation of indigenous people to return to the villages after completing their studies, they act as multipliers of knowledge acquired, mainly in what he said about the health-disease process. This knowledge obtained in a non-indigenous context, not only stimulates the formation of other peoples, but also and mainly the implementation of actions that enable the reduction of risks and continued improvement in health aspects ${ }^{26}$.

Therefore, with a growing presence, the indigenous people with technical training can help in the operationalization of programs that occur with greater effectiveness within communities developed, from the district councils and local health, with subsequent 
approval in the district plan taking into consideration the problems of their daily lives. These actions enable the quest for resources and the realization of projects of research to ensure a better quality of life for their community, as well as the recognition of one's own culture and language, which contributes to a greater adherence of the community in projects ${ }^{8}$.

Until contact with Rondon, the Haliti-Paresí community was composed exclusively by co-opted members of this ethnic group; however, the coexistence with the religious missions forced marriage with other ethnic groups. A strategy that was used for commercial purposes in subsequent years by farmers who sent the supervisors to marry with the indigenous peoples and thus, entering the land Paresí to build farms, houses and appropriating the territory9. Therefore, until the moment the interethnic marriage is a reality in this population and evidenced in this study.

The interethnic marriage causes negative impact. From the perspective of the more traditional indigenous, they believe that this relationship may cause a risk of cultural loss, i.e., the devaluation of the tradition and knowledge, on departure; another portion of the community believes that this union can facilitate access to public services offered in the city ${ }^{27}$.

The impact of marriage with non-Indians has two aspects, when the marriage of a man with an indigenous woman not indigenous, this is accepted as the woman continues with her household chores and does not get involved in political relations of the community. The marriage of an indigenous woman with a man not outsider can cause several conflicts, because this new part cannot give opinion in political decisions and organization of the village ${ }^{21,27}$. Since the marriage between Indians from other ethnic groups do not have the distinctions above, because they are fully incorporated by the community as occur with ethnic Manoki, Nambikwara and Rikbaktsa.

The insertion of non-Indians in the community may even hinder the ethno-development projects, because the fragility of culture with the insertion of new members negatively influences in approval and funding of these projects by government agencies, thus constituting a barrier to the sustainability of indigenous com- munities under this perspective of enterprises in their territories. Silveira emphasizes that it is crucial for the Haliti-Paresí keep the pursuit of political autonomy and support of their material and symbolic needs to be firm in their territories 5 .

The predominance of traditional houses is related with cultural preservation, to represent the myth of origin and the spiritual passage in this world ${ }^{10}$. It also expresses a project of ethno-development of the tourist area where the communities have resumed the traditional architecture as a strategy to provide the visitor the experience of indigenous culture, which has led not only to an improvement in economic conditions, but also to the restoration of cultural ethnicity 5 .

The traditional houses have an oval shape always with your entries directed to sunrise and sunset, are made of raw wood frame collected in the woods nearby, its interior is spacious with dirt, do not have divisions and contain a large amount of inhabitants ${ }^{9}$. The presence of dirt can magnify the risk of enteroparasitosis, since the presence of domestic animals, surface cleaning, moisture and mild temperature becomes the means conducive to the permanence of the parasites in the soil ${ }^{18,28}$.

Over the years the traditional houses have gone through modifications, the Haliti-Paresí are incorporating increasingly industrialized tools and materials, such as wires, nails, cement floor and tiled floors. These new adaptations are justified by the greater durability, protection against insects, rodents, and poisonous animals, in addition to the ease of cleaning.

In the study the number of residents per household ranged from 1 to 9 with an average of 5 people, also influences the increase in the risk of transmission of diseases the fecal-oral route, and among the indigenous communities, the high densities in the same household are well reported. 9 This coexistence next, coupled with the absence of adequate sanitation and the bad habits of hygiene, especially hand washing, contribute greatly to the spread of these diseases among residents in the same housing. 16Cunha and Amichi added that there are several types of parasitic pathogens agents those survive the period of 5 minutes in the hands and 45 minutes under the fingernails, thus enhancing the chances of home con- 
tamination by constant contact ${ }^{29}$.

Furthermore, it should be noted that in the majority of the villages there is weakness in infrastructure, because the water supply is present, however without treatment. The water is collected directly from artesian wells or rivers, stored in a water box, and then distributed directly to the houses that do not have filters. Terças et al. describes that the construction of the villages is next to rivers, but with the reduction of the mesh hydropower projects, reduction of vulnerability propitiated the presence of artesian wells in communities Haliti-Paresi ${ }^{10}$. However, it is necessary to the implementation of educational measures those aim to improve the quality of water for consumption, such as the use of filters, application of hypochlorite, etc.

In the Haliti-Paresi's village where ethno-tourism has been deployed, it is possible to observe the presence of clays filters in homes, in addition to housing with male and female toilets with pipeline for septic, demonstrating that these actions have brought significant improvements to the reorganization of the community, but it is reality in other villages in the study, ${ }^{5,10}$.

Another important risk of environmental contamination that can result in enteroparasitosis in indigenous areas is the disposal of human waste and solid waste in per domestic areas or close to sources of water for human consumption ${ }^{10}$. The sanitation and the evacuation approximately the village cause soil contamination and risk of water contamination that can provide the maintenance of parasitic cycles and the presence in abundance of infective forms in soil and water for human consumption. Thus, the individuals susceptible to parasitism are in constant exposure, with persistent infections that ensures the cycle of transmission of intestinal parasites, ${ }^{46}$.

Is necessary to add the fact that the eliminations of slurry remain close to Haliti-Paresís homes, event that perpetuates the fecal-oral transmission, in which water is the main vehicle for transmission, once the period of rain the digestion which are in the soil can seep into the rivers ${ }^{5,10}$. It should be emphasized that the rivers are also a source of irrigation of crops, required for personal hygiene, washing machine, and leisure ac- tivities especially for children who often use them for entertainment.

The same context can be observed regarding the garbage, whose accumulation and improper disposal on the outskirts of the houses favor the proliferation of vectors, reservoirs and parasites, with subsequent transmission of the infection principally in indigenous children who develop their everyday activities like playing in direct contact with the contaminated soil5.

Escobar-Pardo et al. and Pena and Heller add that due to changes in food habits as the consumption of industrialized foods among the indigenous people, has been observed with the increase in the production of garbage, whose disposal has been conducted in holes next to homes or in its surroundings ${ }^{9}{ }^{20}$.The effective waste collection and disposal in appropriate places would be a factor of paramount importance for preventing health; however, there is only one village that holds your discard in distant location of headquarters, the only one who has the ethno-tourism project in progress.

Although the habits observed in Haliti-Paresí proving that the introduction of industrialized foods is gradually being replaced by traditional nutritional habits and that the epidemiological profile of indigenous peoples has presented an improvement, still there is the occurrence of anemia and malnutrition, often associated with intestinal parasites and weaknesses ${ }^{14,23}$. Other factors can be highlighted in addition to the inadequacy of food, such as the difficulty of access and food production, inadequate use of available foods and other situations of food insecurity ${ }^{30}$.

The improper handling of food should also be highlighted once the enteroparasitosis are transmitted in their great majority through vegetables, fruits and vegetables contaminated ${ }^{29}$. Responsible for the preparation of food for the family, can contaminate, by means of hands, the food they manipulated and thus spread the disease among all those who consume the food, so it is paramount to adoption of actions that prioritize the proper hygiene.

In this context, it is necessary to include the increased production of garbage due to industrialized food, as a consequence of ethno-development. 8 There 
is the importance to establish educational actions on appropriate habits of hygiene and correct handling of food; the habit of improper handling of food and cooking can be the main causes of transmission of enteroparasitas ${ }^{9}, 28$

As for the prevalence of enteroparasitosis in Haliti-Paresí, the overall prevalence was $46.6 \%$, with a predominance of species Giardia duodenal isand Entamoeba histolyticathat contributed to the occurrence of polyparasitism in $23.3 \%$ of individuals. This result is similar to that found by Simões et al. in the XukuruKariri ethnicity in the municipality of Caldas, in thestate of Minas Gerais, where the prevalence was $55.5 \%$ with a polyparasitism of $8.3 \%$, a result lower than that observed in the present study 22 .

Positive samples, $16.6 \%$ and $6.7 \%$ of the parasites were found Giardia duodenalis andEntamoebabistolytica, respectively. A study conducted in the Xavante reservation, in the state of Mato Grosso by Silva found that $61.2 \%$ of the Indians showed positivity for parasitism, 6.1\% for Giardia duodenalisand $7.7 \%$ for Entamoeba bistolytica and polyparasitism in $25.5 \%$ of individuals. 15In a third study conducted with ethnicity Maxacali in the Minas Gerais, detected a high prevalence (84.3\%), predominantly related to Entamoebabistolytica (48.9\%) and Ancilostomideo (37.9\%) results different from those identified in this study ${ }^{18}$.

In the State of Paraná, Toledo et al. studied the Kaingang population found that $65.8 \%$ of the indigenous peoples had Entamoeba coli and 34.9\% of Endolimax $n a n a^{17}$. More recently in Alagoas, in a study developed with the indigenous Xucurukariri it was possible to identify a prevalence of $60 \%$ and $1.8 \%$ for Entamoeba coli and Endolimax nana, respectively, whose result discrepancy can be explained by environmental factors not favorable to the proliferation of these agents in these areas ${ }^{22}$.

The high rates of polyparasitism described here are similar to other findings involving indigenous communities ${ }^{16,17,18,19,20,22,25}$. Similar environmental conditions, in respect to precarious sanitation and life habits, conduct to maintenance of the biological cycle of parasitic agents.

Habits commonplace in villages favors the contamination of the environment, making it more conducive to the proliferation of several pathogens those justify the high rates of polyparasitism in the villages ${ }^{25}$. However, it is pertinent to note that, with the conception of knowledge about the health-disease process to increase the ability of the individual to acquire a holistic vision about the issues that surround it, to change their behavior in such a way that continue to seek ways to ensure an improvement in the quality of life ${ }^{31}$.

Therefore, there is a clear need for a greater attention to the enteroparasitosis, whereas the lack of adequate sanitation and hygiene can directly influence the quality of life of the population, particularly the indigenous population ${ }^{18,20,22,25}$.

Finally, it is possible to check the great challenge of proposing an integration between the control of enteroparasitosis and sanitation with the ethno-development, considering the different aspects, social, political, economic and cultural rights, with exploitation of indigenous traditional knowledge and respect to the forms chosen for the construction of its future projects implemented in the definition of ethno-development ${ }^{8}$.

The main limitation of this study was the low adherence in the delivery of collectors with stool samples. It was noticeable that, in accordance with the engagement of local leaders, the frequency of participation on the part of the village was greater, as observed in the village Wazare.

\section{CONCLUSION}

The study conducted in Utiariti indigenous land, where reside the Haliti-Paresí, identified high rates of intestinal parasitoses $(46,6 \%)$ and although it has confirmed the existence of problems in sanitation, difficulty to access to treated water, inadequate destination to waste and garbage enabled the identification of innovative initiatives guided by the ethno-development as an important path to overcome the difficulties and challenges associated with the culture.

Pass through innovation that will boost the change and at the same time preserves the culture, values, beliefs, myths and rites is a new step that is implemented. Even because some actions focused on the economic ethno-development these communities are already affecting improvements in health and sanitation, as for example, 
the structure of the village to ethno-tourism that provides access to toilets, water filters and dispose of garbage away from the houses. This is the beginning of a discussion to be inserted into the daily lives of indigenous leaders and paved in order to raise the standard of living of these communities.

All individuals infected with pathogenic parasites were treated in accordance with the protocols recommended by the Ministry of Health, being met by the health team of the DSEI-Cuiabá, is also a partner in this study.

The periodic coproparasitological investigations, including the determination of the parasitic load, it is necessary for the control of enteroparasitosis in indigenous communities, as well as for the evaluation of strategies and measures to combat this form of parasitism.

\section{REFERENCES}

1. Basta PC, Orellana JDY, Arantes R. Perfil epidemiológico dos povos indígenas no Brasil: notas sobre agravos selecionados. Brasília: MEC-SECADI; 2012.

2. Garnelo L, Pontes AL. Saúde Indígena: uma introdução ao tema. Brasília: MEC-SECADI; 2012

3. IBGE. Instituto Brasileiro de Geografia e Estatística. Os indígenas no censo demográfico de 2010. Rio de Janeiro; 2012. Avaiable from: https://ww2.ibge.gov. br/indigenas/indigena_censo2010.pdf

4. Canova L. Doces bárbaros - imagens dos índios Paresi no contexto da conquista portuguesa em Mato Grosso (1719-1757). Dissertação (Mestrado em História). Universidade Federal de Mato Grosso; 2001. Avaiable from: http://ivros01.livrosgratis.com.br/ cp000214.pdf

5. Silveira EMS. Cultura Como Desenvolvimento Entre Os ParesiKozarini. Dissertação (Mestrado em Antropologia Social). Universidade Federal Rio Grande do Norte; 2011.

6. Verdum R. Etnodesenvolvimento e mecanismos de fomento do desenvolvimento dos povos indígenas. In: Lima ACL, Barroso-Hoffmann M. (org.). Etnodesenvolvimento e Políticas Públicas: Bases para uma Nova Política Indigenista. Rio de Janeiro: Contra Capa; 2002.
7. Palenzuela P. 2009. Mitificación del desarrollo y mistificación de la cultura: el etnodesarrollo como alternativa, Iconos Rev de ciencias sociales [internet] 2009 [acesso em 2017 Jun 16]; 33: 127-140. Avaiable from: http://www.flacso.org.ec/docs/33palenzuela. pdf

8. Ministério da Saúde (Brasil). Ministério da Saúde, Secretaria Executiva. Programa Saúde Indígena: Etnodesenvolvimento Desenvolvimento das Sociedades Indígenas. Brasília: Ministério da Saúde; 2001. Avaiablefrom: http:/bvsms.saude.gov.br/bvs/publicacoes/ saude_indigena.pdf

9. Pena JP, Heller L. Saneamento e Saúde Indígena: Uma Avaliação na População Xakriabá, Minas Gerais. EngSanitAmbient. [internet] 2008 [acesso em 2018 Jan 13];13: 63-72. Avaiablefrom: http://www.scielo. br/pdf/esa/v13n1/a09v13n1.pdf

10. Terças ACP, Nascimento VF, Hattori TY, Zenazokenae LE, Atanaka M Lemos ERS. Os Haliti-Paresí: uma reflexão sobre saúde e demografia da população residente nas terras indígenas Paresí. Rev Ameríndio. [internet] 2016 [acesso em 2018 Jan 22];10: 226-253. Avaiablefrom: http://seer.ufrgs.br/index.php/EspacoAmerindio/article/view/60301

11. Terças ACP, Nascimento VF, Hattori TY, Zenazokenae LE, Atanaka M Lemos ERS.Clinical research production in indigenous area: experience report with the Haliti-Paresi. Revenferm UFPE online[internet] 2016 [acesso em 2018 Jan 22]; 10: 2253-2261. Avaiable from: https://periodicos.ufpe.br/revistas/revistaenfermagem/article/view/11241/12847

12. Ritchie, L.S. An ether sedimentation technique for routine stool examinations. Bull. U.S. Army Med. Dept., 8: 326, 1948.

13. Young, K.H. et al. Ethyl Acetate as a substitute for diethyl ether in the formalin-ether sedimentation tecnique. J. Clin. Microbiol., 10: 852-3, 1979.

14. Santo SRV, Coimbra Júnior CEA. Cenários e tendências da saúde e da epidemiologia dos povos indígenas no Brasil. Rio de Janeiro: ABRASCO/ Fiocruz; 2003. Avaiable from: http:/books.scielo.org/id/bsmtd/pdf/ coimbra-9788575412619-02.pdf

15. Marucci MFN. Os povos indígenas e a construção das políticas de saúde no Brasil. Cad Saúde Publica 2004; 20: 871-72. 
16. Rios L, Cutolo SA, Giatti LL, Castro M, Rocha AA, Toledo RF et al. Prevalência de parasitoses intestinais e aspectos socioambientais em comunidade indígena no distrito de Iauaretê, município de São Gabriel da Cachoeira (AM), Brasil. Saúde Soc.[internet] 2007 [acesso em 2018 Mar 05]; 16: 76-86. Avaiable from: http://www.scielo.br/scielo.php?pi$\mathrm{d}=$ S0104-12902007000200008\&script $=$ sci_abstract\&tlng $=\mathrm{pt}$

17. Silva GMV. "Parasitos intestinais na comunidade indígena Xavante de Pimentel Barbosa, Mato Grosso, Brasil”. Dissertação (Mestrado em Saúde Pública). Escola Nacional de Saúde Pública Sergio Arouca, Rio de Janeiro; 2010. Avaiable from: https://www.arca. fiocruz.br/bitstream/icict/24558/1/1064.pdf

18. Assis EM, Olivieria RC, Moreira LE, Pena JL, Rodrigues LC, Machado-Coelho GLL.Prevalência de parasitoses intestinais na comunidade indígena Maxakali, Minas Gerais, Brasil. Cad Saúde Pública [internet] 2013 [acesso em 2018 Mar 05];4: 681-690. Avaiable from: http://www.scielo.br/scielo.php?pi$\mathrm{d}=$ S0102-311X2013000400006\&script $=$ sci_abstract\&tlng $=\mathrm{pt}$

19. Toledo MJO, Paludetto AW, Moura FT, Nascimento ES, Chaves M, Araújo SM et al. Avaliação de atividades de controle para enteroparasitose em uma aldeia Kaingáng do Paraná. Rev Saúde Pública. [internet] 2013 [acesso em 2018 Mar 05];43: 981-990. Avaiabl from: http://www.scielo.br/scielo.php?pid=S0034-8 $9102009000600009 \&$ script $=$ sci_abstract\&tlng $=$ pt

20. Escobar-PardoML, GodoyAPO, MachadoRS, Rodrigues D, Neto Ulysses F, Kawakami E.Parasitoses em crianças indígenas do Xingu. Jornal da pediatria[internet] 2010 [acesso em 2018 Jan 22];86: 493-496. Avaiable from: http://www.scielo.br/scielo.php?script $=$ sci_arttext\&pid $=$ S0021-75572010000600008\&lng $=$ en.

21. Paes MHR. A questão da língua na escola indígena em aldeias Paresi de Tangará da Serra-MT. Rev Brasileira de Educação[internet] 2002 [acesso em 2018 Jan 22];21: 52-60. Avaiable from: http://www.scielo. br/pdf/rbedu/n21/n21a04.pdf

22. Simões BS, George LLMC, Pena JL, Freitas SN. Condições ambientais e prevalência de infecções parasitárias em indígenas Xukuru-Kariri, Caldas, Brasil. Rev panam salud publica[internet] 2015 [acesso em 2018 Jan 22];38: 42-48. Avaiablefrom: https://www. scielosp.org/article/rpsp/2015.v38n1/42-48/
23. Coimbra Júnior CEA, Santos RV. Parasitismo intestinal entre o grupo indígena Zoró, Estado de Mato Grosso (Brasil). Cad Saúde Pública. [internet] 1991 [acesso em 2018 Jan 22];7: 100-103. Available from: http://www.scielo.br/scielo.php?script $=$ sci_arttex$\mathrm{t} \& \mathrm{pid}=$ S0102-311X1991000100009\&lng $=\mathrm{en}$

24. Bóia MN, Carvalho-Costa FA, Sodré FC, Porras-Pedroza BE, Faria EC, Magalhães GAPinto et al. Tuberculose e parasitismo intestinal em população indígena na Amazônia brasileira. Rev Saúde Pública[internet] 2009 [acesso em 2018 Fev 13];43: 176-178. Available from: http://www.scielo.br/scielo.php?script $=$ sci_arttext\&pid $=$ S0034-89102009000100023\&lng $=$ en

25. Oliveira RB, Fernandes PC, Nascimento BWL, Fernandes FV, Castro CLF et al. Fatores associados a ocorrência de parasitoses intestinais em uma população de crianças e adolescentes. Rev Paul Pediatr. [internet] 2012 [acesso em 2018 Fev 13];30: 195-201.Available from: http://www.scielo.br/scielo.php?script $=$ sci_arttext\&pid $=$ S0103-05822012000200007\&lng $=$ en

26. Salgado CAB. Segurança alimentar e nutricional em terras indígenas. Rev Estudos e Pesquisas[internet] 2007 [acesso em 2018 Fev 13]; 4: 131-186.Avaiable from: http://www.funai.gov.br/arquivos/conteudo/ cogedi/pdf/revista_estudos_pesquisas_v4_n1/ 04-Carlos_Antonio_Bezerra_Salgado-Seguranca_alimentar_e_nutricional_em_terras_indigenas.pdf

27. Lasmar C. Irmã de índio, mulher de branco: Perspectivas feministas do Alto Rio Negro. Mana[internet] 2008 [acesso em $2018 \mathrm{Fev}$ 13];14: 429-454. Avaiable from: http://dx.doi.org/10.1590/S010493132008000200006

28. Cutolo AS, Matté MH, Rocha AA. 2006. Monitoring of parasitological contamination in treated was te water from activatedsludge system. Management of Environmental Quality[internet] 2006 [acesso em 2018 Fev 13];17:43-56. Avaiable from: https://www.emeraldinsight.com/doi/abs/10.1108/14777830610639431

29. Cunha LF, AmichiKR. Relação entre a ocorrência de enteroparasitoses e práticas de higiene de manipuladores de alimentos: revisão da literatura. Revista Saúde e Pesquisa[internet] 2014 [acesso em 2018 Mar05];7: 147-157. Avaiable from: http://periodicos.unicesumar.edu.br/index.php/saudpesq/article/view/2634 
30. Leite MS, Santos RV, Coimbra Júnior CEA, Gugelmin SA. Alimentação e Nutrição dos Povos Indígenas no Brasil. Rio de Janeiro: Fiocruz/ Atheneu; 2007.

31. Souza TJ. O processo saúde-doença em indígenas. Periódicos Univag[internet] 2017 [acesso em 2018 Mar05];2: 03-05. Avaiable from: http://www.periodicos.univag.com.br/index.php/CONNECTIONLINE/ article/viewFile/386/598

Recebido em: 25/10/2018

Aceito em: 21/05/2019 